\title{
An Analysis of the Effects on Application of Management Accounting Information Systems and Quality Management Accounting Information
}

\author{
Widia Astuty \\ Universitas Muhammadiyah Sumatera Utara, Medan, Indonesia \\ widiaastutyfajar@yahoo.com
}

\begin{abstract}
The study aims to prove empirically; (i) the influence of the business environment for the application of management accounting information systems; (ii) the influence of ethics on the application of management accounting information systems; (iii) the influence of organizational culture on the implementation of management accounting information systems; and (iv) the effect of the application of management accounting information system on the quality of management accounting information. The motivation of this study due to a phenomenon of having an integration on management accounting information system whereby the information generated is not qualified, as well as the uncertainty of business environment, ethics and organizational culture which are yet to have optimal conditions. The method used is explanatory research with a survey approach, using a statistical tool of SEM Partial Linear Regression, with the aim to obtain facts concerning the occurance of phenomena, seek actual and systematic information on the application of management accounting information systems, and the quality of accounting information management. The results showed that all variable of the business environment, ethics, organizational culture affect the application of accounting information management system; and the application of management accounting information system affects the quality of information management accounting.
\end{abstract}

Keywords: Business Environment, Ethics, Organizational Culture, Application of Management Accounting Information System, Quality of Information Management Accounting

\section{Introduction}

The service industry is one industry that progressing very rapidly and have a very important role in the Indonesian economy. Indonesia has many service sector industries such as the hospitality, tourism, restaurants, transportation, telecommunications, banking services and other services. These sectors are experiencing significant growth from year to year. The most potential industry that has significant growth is the hospitality industry. Hotel is a type of accommodation that use some or entire buildings that provide lodging, food and beverage and other supporting services for the managed common commercially. The progress of the hospitality industry is highly driven by the development of the tourism industry, business, easy access to transport and supported by adequate infrastructure. The growth of the hospitality business in Indonesia seem more spectacular, it is seen in the vigorous number of business people of this industry that have extended their business to various regions in Indonesia, including North Sumatra such to build new hotels in an area that is fairly potential as well as in tourist area. At first, the growth of the hospitality industry is more focused on the development of the tourism sector. It can be seen from the establishment of the hotel resorts that is closely established in a tourist attraction. These hotels provide income in the form of foreign exchange for the country and creation of new jobs for the community. However along with the economic development, the hotel is not only used as a supporter of the tourism industry but has shifted to one of the business-oriented service industry. Therefore, a competition is a very important factor to be considered by the management in running the company to compete globally. Each product created by a company not merely anticipating on how it's penetrated to the market but more unlikely to compete closely with similar products in the same industry that constantly introducing a new innovation.

In understanding the challenges and opportunities in the hospitality industry, the managers in this sector requires information that brings together financial and non-financial data which are relevant to decisionmaking in order to perform various breakthroughs and continuous innovations. The businessmen in this sector should understand that they can not rely on primary products (core product) in order to survive and thrive beside to provide excellent service to hotel guests, but they also required to create additional product (augmented products) to support the main products offered to hotel guests. The financial and 
non-financial data information generated from the financial management accounting information system which it's development greatly influenced by changes in the corporate environment. Most management decisions require information that unifies financial and non-financial data conventionally resulted from the application of accounting information systems (AIS) and management information systems (MIS) which functioned independently. Both of these data sets will then be integrated and reported to the manager. The task of providing the managers on integrated information will be inefficient and costly when the information support system is not integrated. Moreover, the lack of coordination between the financial and non-financial system can produce bad management decisions.

Conventionally, the design of management accounting system has a orientation to the internal financial information organization based on historical data. With the increasing problem-solving task faced by the management, the management accounting system's design not only oriented to the financial data but to external and non-financial data (Mia \& Chenhall, 1994). Mock (1971) suggested that the information has potential value, because it can make a direct contribution in determining the choice, managers can improve the understanding of the real world and be able to identify the relevant activities. Chenhall and Deigan (1986) found empirical evidence that there are four characteristics of useful information as perceived by managers produced by the management accounting system, namely the scope of the breadth, timeliness, aggregation, and integration. The breadth of scope of information provides information about external factors and internal companies, non-economic and economic information, estimates the incidences that may occur in the future and environmental aspects. The punctuality shows the interval between the request for information with the desired information presentation and reporting frequency information. While, the timeliness of the information would affect the ability of managers to make the right decision. Timely information will be valuable if delivered before losing its capacity to influence decisions that will be made by the manager as well as will make the manager able to deal with environmental uncertainty being faced effectively.

The aggregated information is the information that can reflect the functional area of responsibility of the managers or in other words it directs managers to become more responsible in each area. In this aggregated information, the implementation of a form of formal policy (such as discounted cash flow) is taken into account or information analytical models that are based on the final results of the functional areas (such as marketing, production) or based on time i.e monthly or quarterly. With clear information about the area of functional responsibility of the manager, it will reduce the likelihood of conflict. If the aggregated information presented properly, it will provide meaningful input for managers in the decision-making process because the time needed to evaluate of receiving the information is less. Thus the manager's expectation on performance can be increased due to use of integrated information. The characteristics of the available information will be effective if in accordance with the requirements of the user of the organizations. This is in line with the contingency approach proposed by Otley (1980) that the availability of the respective characteristics of management accounting information is not the same for all situations.

The environment is the physical and social factors that directly serve as a consideration in the decisionmaking in the organizations (Duncan, 1972). Abernethy and Guthrie (1994) states that the application of management accounting information systems in companies affected by the uncertain environment, therefore environmental uncertainty is applied as a factor that can influence the management strategy, information systems and accounting (Chenhall \& Deigan 1986). While Vanevenhoven (2008 p. 10) refers the environment as the set of changes of all objects in whose attributes are changed by the behavior of the system gap. The environment embedded with uncertainty, while the source of uncertainty used as the external environment of the company that can not be predicted (Milliken, 2001) i.e. suppliers, competitors, government, distributors and customers. Similarly Khan and Jain (2007) mentioned that the uncertainty can be added in the possibility of shifting consumer, actions of competitors, technological developments and changes in the economic or political environment. Milliken (2001) suggest that a changing of environment, complexity and heterogeneity makes the environment less predictable. An increasing uncertain global economy with rapid technological advances, therefore customers are constantly changing, deregulation increases and demands to leave the trade barriers.

Given the importance of the external environment for a company, it is necessary to perform the alignment between the capabilities of companies with environmental changes that occur continuously. According to Boyd et al., (1993), there are two approaches to measuring the external environment, namely; the objective environmental perceptual environmental measures. Measurement of the external environment 
with the objective approach conducted using data such as industry data, industry sales growth and industry concentration ratio (Boyd et al., 1993). While the measurement of the external environment with the subjective approach is done by using attention and interpretation of managers as key informants from the environment faced by the company. This allowed the researchers describe the external environment from the members' perspective of the organization in this case managers and top managers (Boyd \& Fulk, 1996). The success or failure of a company is largely influenced by human administrators. The same environment that is perceived by a company as something uncertain and complex can be seen as static environment and easily understood by other companies, even the managers within the same company saw the environment in different ways. This difference could arise based on the background, education, and functional parts where the managers work.

On the other hand, there is a dilemma on the accountant ethical management whereby the management accountant asked to provide inappropriate information (Hansen \& Mowen, 2007, p.20). For an example, the management accountant asked by his/her boss to prepare information/reports that are believed as something that biased and untrue, thus the management accountants are in the last row in the fight for honest behavior due to strong pressure from his/her superiors (Atkinson et al., 2012, p.20). Atkinson et al. (2012, p.19) argues that ethics is a moral system or set of values used to set the behavior of individuals. Furthermore, Atkinson stated that efforts are being made to establish the universal values' systems are not progressing because each individual is guided by different ethical systems, while the organizations will be greatly influenced by legal or social sanctions generated by the employees' unethical behavior. Furthermore, Atkinson et al. (2012, p.19) argues that ethical errors can have a major impact on the organization and its employees as happened by the staff of KPMG in Unites States where they have to pay a fine of $\$ 500$ million and received legal sanction because some employees involved in the preparation of the dubious tax protection for its clients. Similarly mentioned by Hansen and Mowen (2007, p.20) that a series of financial scandals is occurs involving Enron, Tyco International, WorldCom and other companies that trigger special attention on business ethics.

The ethical behavior involves selecting the correct actions, appropriate and fair (Hansen \& Mowen, 2007, p.20). It is important for companies to have ethics policies in the application of its information system (Loudon \& Loudon, 2008, p.152) as the framework to draw certain attitudes that must be followed by all employees where they touch and move with fellow employees or other elements in a corporate environment because human behavior can affect the accounting data and business decisions (Lubis, 2010, p.15). Similarly as stated Kallapur and Krishnan in Chapman et al. (2009, p. 1400) that ethics is an influential in accounting. This is supported by Brooks and Dunn (2010, p. 350) that it is important to adhere the ethical values which have been determined for professional accountants who work in management, as an employee or a consultant. Similarly revelead by Duska et al. (2011, p.230) that the practitioners of management accounting and financial management have an obligation to the community, their profession and organizations to maintain the highest standards of ethical codes.

To improve the ethical behavior of its employees, many organizations formulate and institutionalize ethics control system (Atkinson et al., 2012, p.19). The Institute of Management Accountants - IMA, announced a code of ethical standards for management accountants. The standards are aligned with the intent to achieve the objectives of management accounting (Garisson et al., 2011, p. 30) and make it as a code of conduct and action to build a system that oversees, spur, and strengthen individual behavior that is consistent with the set of organization's code of ethics (Atkinson et al., 2012, p.21). The ability of a professional to be able to understand and be sensitive on the presence of ethical issues in the profession is strongly influenced by the society, organization or places wherever he/she works as well as his/her personal experience (Hunt \& Vitell, 1986 in Khomsiyah and Nur, 1998). When individuals join in an organization, they bring their own values and beliefs and quite often those values and beliefs help individuals succeed in the organization, however they need to learn how companies are doing something (Luthon, 2005, p.110). The organizational culture relates to how employees understand the characteristics of an organization. It seeks to measure how employees view their organization so it is expected that individuals who have different backgrounds or levels will understand the organization with similar meaning (Robbin \& Judge, 2007).

The organizational culture involves expectations, values, and attitudes together, it gives effect to the individual, group, and organizational processes, while the organization is able to operate efficiently when there is a value which believed to be shared among employees (Ivancevich et al., 2011). Meanwhile, the culture is an internal environment that seen and felt by those who work in it which illustrates how human 
resources to learn in doing things whereby it often considered as an absolute strength (Azhar, 2008, p.60). A similar argument is mentioned by Ginanjar (2010) that the problems arise in a multicultural culture where many public officials who do not qualify, thus the public services, social and economic life of local residents are getting worse. The involvement in the process of implementation of information systems is seen as an important factor to bring a change of attitude which, in turn, facilitate organizational change. Any changes in information systems forcing the human resources to do something different than usual. Any attempt made will keep pushing the old information system persist, therefore the information system designers can not change the norms when designing an information system for enterprises' organizations which has become a culture in the organization of the company (Azhar, 2008, p.60). Similarly revealed by Leidner and Kayworth (2006) that understanding the culture used as an important action to assess the information system because the every culture levels can affect the successful of information systems' implementations within an enterprise. The culture can shape and provide guidance in developing information systems in organizations and it plays an important role in the managerial process, either directly or indirectly influence the information systems (Leidner \& Kayworth, 2006).

According to Claver et al. (2001), the human is an important component in information systems, so that it can be considered that the organizational culture related to information systems. By understanding the human behavior that is influenced by something in an organization, the potential impact of the implementation of information systems can be clarified (Cabrera, 2001). Based on the phenomena that have been disclosed above, the author has an interest to study on the effect of business environment, ethics, culture, application of management accounting information systems and quality of management accounting information in the hotels service industry companies in North Sumatera.

\section{Methodology}

The scope of this research is the business environment, ethics, organizational culture, the application of management accounting information systems and quality management accounting information. While the research method employs is an explanatory research that used to obtain a description, a systematic picture, factual and accurate information on the facts, the nature and relationship between variables (Sekaran \& Bougie, 2010, p. 123).

\section{Operationalization of Variables}

Table 1: Operationalization of Variables

\begin{tabular}{|c|c|c|c|c|}
\hline Variable & Dimension & Indicator & $\begin{array}{l}\text { Question } \\
\text { naire No. }\end{array}$ & Scale \\
\hline $\begin{array}{l}\text { Business } \\
\text { Environment } \\
\text { (Duncan, 1972) } \\
\left(\mathrm{X}_{1}\right)\end{array}$ & $\begin{array}{l}\text { Internal } \\
\text { Environment } \\
\text { External } \\
\text { Environment }\end{array}$ & $\begin{array}{l}\text { Organisation Personnel and Functions, Staff } \\
\text { Unit, and Organization Levels. } \\
\text { Customers, Suppliers, Social Competitors, } \\
\text { Politics and Technology }\end{array}$ & $9-24$ & Ordinal \\
\hline $\begin{array}{l}\text { Ethics } \\
\left(\mathrm{X}_{2}\right)\end{array}$ & 1. Competence & $\begin{array}{l}\text { 1. Maintaining professional competence } \\
\text { through the development of knowledge and } \\
\text { skills on an ongoing basis }\end{array}$ & $25-42$ & Ordinal \\
\hline $\begin{array}{l}\text { Management } \\
\text { Accountant } \\
\text { Professional } \\
\text { Ethics, Institute } \\
\text { Of } \\
\text { Management }\end{array}$ & & $\begin{array}{l}\text { 2. Carry out professional duties } \\
\text { according to the laws, regulations and } \\
\text { technical standards } \\
\text { 3. Prepare complete reports, clear and } \\
\text { provide appropriate recommendations, and } \\
\text { provide information that is relevant and }\end{array}$ & & \\
\hline $\begin{array}{l}\text { Accountants, } \\
\text { (Hansen and } \\
\text { Mowen, 2007, } \\
\text { p.22; Garrison } \\
\text { et al., 2011, } \\
\text { p.30-31) }\end{array}$ & 2.Confidentiality & $\begin{array}{l}\text { reliable } \\
\text { 1. Refrain from disclosing confidential } \\
\text { information. } \\
2 \text { Inform subordinates about the } \\
\text { confidentiality of information obtained and } \\
\text { monitor subordinates to maintain the } \\
\text { confidentiality. }\end{array}$ & $43-48$ & \\
\hline
\end{tabular}




\section{Integrity}

4. Objectivity

1) Artifacs

Organization Culture

$\left(\mathrm{X}_{3}\right)$

(Luthon,

2005, p. 110;

Champoux,

2003, p.71;

Robbins and

Judge, 2007,

p.511) 2003, p.71)
3. Refrain from using confidential information obtained for personal use

1. Avoid any conflict of interest and provide advice to the parties involved in the conflict.

2. Refrain from engaging in activities that can reduce the ability to perform tasks ethically.

3. Reject any form of gift, souvenir, or hospitality which may affect the action which inhibits either the achievement of organizational goals actively or passively.

4. Recognize and communicate the professional limitations or other constraints that would preclude responsibility assessment.

5. Communicating favorable and unfavorable information and give an opinion or professional judgment.

6. Refrain from engaging or supporting activities that could discredit the profession.

1. Communicate information fairly and objectively.

2. Disclose all relevant information to affect users on the report, comments, and recommendations presented

4.

1. The presence of human interaction (Luthon, 2005, within the company using the same p.110, Champoux, terminology

2. The existence of mutual respect in interactions

3. The presence of a conducive organizational climate and the presence of adequate physical layout

4. The presence of strict rules to interact within the organization.

2) Norms

(Luthon, 2005, The presence of behavioral p.110) guidelines/standards; guidance on the work to be done.

3)Dominant Value

(Luthon, 2005, $1 . \quad$ Produces high quality products.

p.110, Champoux, 2. It has a low rate of absenteeism.

2003, p.71, 3. The presence of high efficiency.

Robbins and 4 . The degree to which the employee is Judge, 2007, able to work and compete aggressively.

p.511)

4) Basic 1. The presence of a good relationship Assumption between the individual in organization.

(Champoux, 2. The presence of a good relationship 2003, p.71) with the elements of organization's external environment 
Application of

Management

Accounting

Information

Systems (Y)

(DeLone \&

McLane,

2008)

3) System Use

Quality of management accounting information

(Z) (McLeod \& Schell,

2007, p.65;

Deigan \&

Chenhal, 1985)

,

1) Relevance 2007, p.65)

2) Accuracy

2007, p.65)
1) System Quality

2) Service Quality

Service Quality

(McLeod \& Schell,

(McLeod \& Schell, situation.

3) Completeness (McLeod \& Schell, 2007, p.65)

4) Timeliness

(McLeod \& Schell, 2007, p.65;

Deigan and

Chenhal, 1985)

5) Broadscope

(Deigan \&

Chenhal, 1985)

6) Aggregation

(Deigan

Chenhal, 1985)

7) Integration

(Deigan

Chenhal, 1985)

Information is available or existed at the time

the information is needed.

1. The ability of the system to respond

to the needs.

2. The system has timeliness in processes

Level of use and purpose of use

The presence of the suitability of the 49-59

generated information as required.

The generated information reflect the actual

The information provided must be complete

Have information that can estimate future

events.

Information presented is precise and complete. $\&$

Information reflects the relation between \& parts or sections

Population dan Sample: Population refers to a whole group of people, events or things of interest that intended to be analyze in a research (Sekaran \& Bougie, 2010, p. 121). In determining the members of population if the subject is less than a hundred, it suggested to take all the number of population which is called as a population study (census). Based on the above statement, thus the sample of the target population in this study were carried out by taking the entire hospitality services' companies in North Sumatera province with total of 32 hotels where it is used as the unit of analysis. Furthermore, the respondents in this study is the manager of the hotel, cashier, customer service, staff in accounting and IT departments using a questionnaire as a tool in collecting the data. Meanwhile, the methods in collecting data used is a survey method.

Instruments Measurement: The validity test is done to measure the statements contained in the questionnaires. A statement is valid if the statement is capable of measuring what is to be measured and reveal on to be disclosed. While, the reliability test refers to an index that shows the extent of the measuring instrument can be trusted or can be reliable. It is to be stable and reliable when the use of such measuring instruments repeatedly give similar values (Singarimbun \& Sofian Effendi, 1995, p.138).

Analysis and Hypothesis Test: The analysis used to test the hypothesis in this study is Structural Equation Modeling (SEM) using a program tool of Analysis of Moment Structure (AMOS) version 16 and estimating the parameters in the model adopted by the method of Partial Least Square (PLS) on the basis 
of the variance. SEM is a set of statistical techniques that allow the testing of a set of relationships that are relatively "complex" simultaneously. For purposes of analysis, since all variables are in ordinal scale, while the use of path analysis requires the data with the interval measures, then the ordinal data is transformed into interval data via the Method of Successive Interval.

\section{Findings}

Questionnaire Distribution Return Rate: With regard the questionnaire return rate, it suggests that the rate of return of $30 \%$ considered a good rate, and will be even better when it reaches $70 \%$. Thus, the questionnaire return rate of $96.09 \%$ in this study is a very good return rate as depicted in Table 2 below:

Table 2: Questionnaire Distribution Return Rate

\begin{tabular}{lllll}
\hline $\begin{array}{l}\text { Total } \\
\text { Respondent }\end{array}$ & $\begin{array}{l}\text { Questionnaire } \\
\text { Distributed }\end{array}$ & $\begin{array}{l}\text { Questionnaire } \\
\text { Return }\end{array}$ & $\begin{array}{l}\text { Non-analyzed } \\
\text { Questionnaire }\end{array}$ & $\begin{array}{l}\text { Analyzed } \\
\text { Questionnaire }\end{array}$ \\
\hline 256 & 256 & 246 & 11 & 235 \\
& $100 \%$ & $96.09 \%$ & $4.29 \%$ & $91.79 \%$ \\
\hline
\end{tabular}

Influence of Business Environment, Ethics, and Organization Culture on the Implementation of Management Accounting Information System and its Impact on the Quality of Management Accounting Information: To answer the research problems related to the influence of the business environment, ethics and organizational culture on the implementation of management accounting information systems and the effect of the application of management accounting information system on the quality of management accounting information, this study used Structural Equation Modeling (SEM) approach Partial Least Square (PLS). The consideration of using Partial Least Square (PLS) due to a large number of samples. The unit analysis of the sample on hospitality services company is as many as 32 hotels. The results of the hypothesized full path diagram model is obtained using the Smart PLS 2.0 as follows:

Figure 1: Path Analysis Diagram

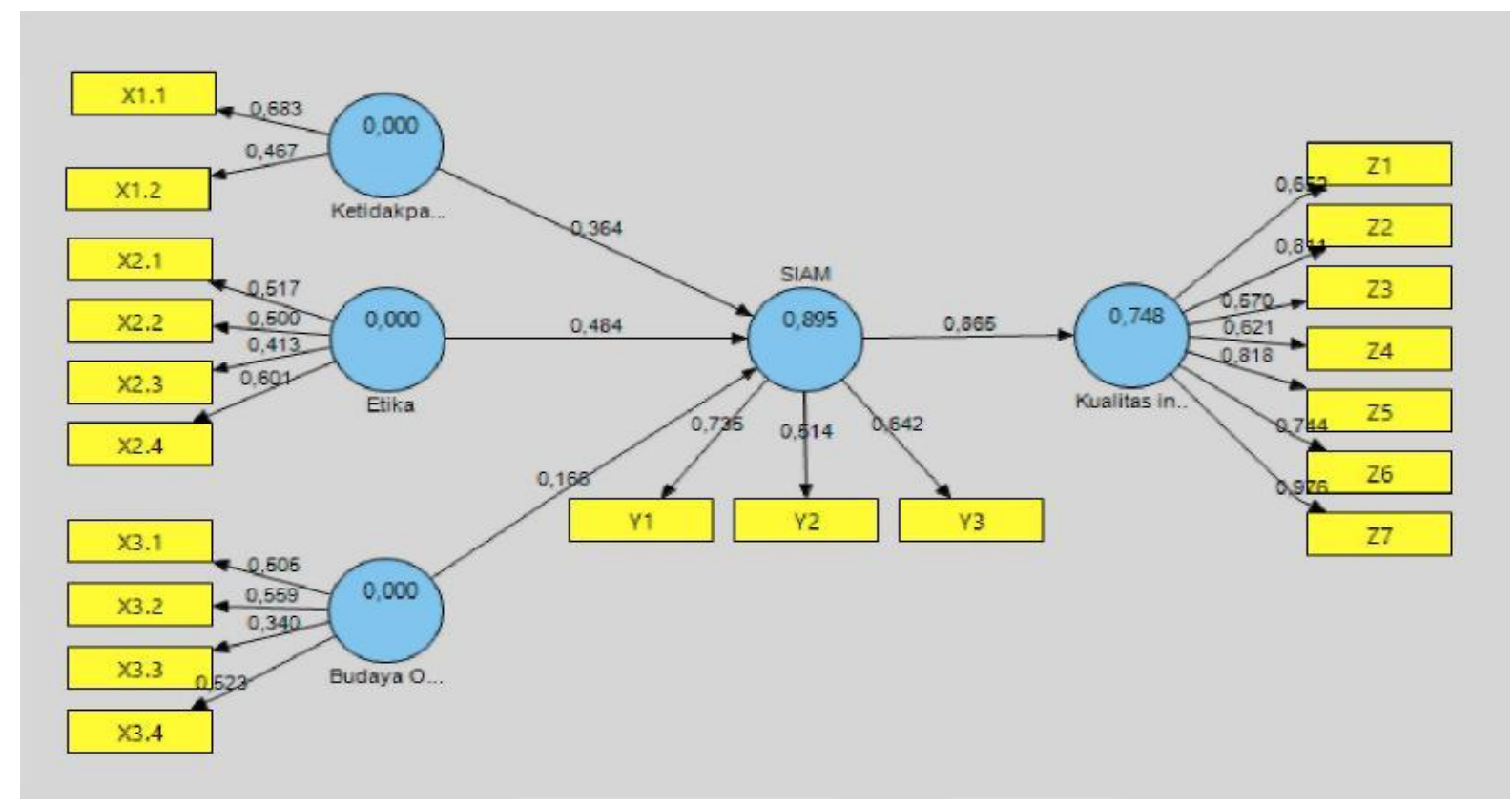

The structural models in this study consists of two sub-structure, the first model is the influence of the business environment, ethics and culture organization of the implementation of management accounting information systems; and second model is the influence of the management accounting information systems on the quality of management accounting information.

The results obtained for the first structural model is as follows: 


$$
Y=0.364 X_{1}+0.484 X_{2}+0.168 X_{3}+0.105
$$

The results of multiple regression above, can be described as follows:

- Any increase of one unit in $X_{1}$ (business environment) causes $Y$ (application of management accounting information systems) rose by $36.4 \%$ or 36.4 units.

- Any increase of one unit in $\mathrm{X}_{2}$ (ethics) causes $\mathrm{Y}$ (application of management accounting information systems) rose by $48.4 \%$ or 48.4 units.

- Any increase of one unit in $\mathrm{X}_{3}$ (organizational culture) causes $\mathrm{Y}$ (application of management accounting information systems) rose by $16.8 \%$ or 16.8 units.

The structural equation model for the effect of the application of management accounting information system on the quality of management accounting information is as follows:

$$
\mathrm{Z}=0.866 \mathrm{Y}+0.252
$$

A simple regression result above can be explained as follows:

Any increase of one unit in Y (application of management accounting information systems) causes the $\mathrm{Z}$ (quality of management accounting information) rose by $86.5 \%$ or 86.5 units.

The results of the path diagram of the overall model will describe the magnitude of the path coefficients and statistical t-test values for each hypothesized pathway structure. An evaluation of the model is done by looking at the results of the measurement model (outer model) and the structural model (inner model) from the investigated models.

The Effect of Business Environment on the Application of Management Accounting Information Systems: The business environment is hypothesized to affects the application of management accounting information system. The results of significance test of the hypothesis as follows:

Ho. $\gamma 1=0: \quad$ The business environment does not affect the application of management accounting information systems.

Ha. $\gamma 1 \neq 0$ : The business environment affects the application of management accounting information systems.

Table 3: Significance test of the Effect of Business Environment on the Application of Management Accounting Information Systems

\begin{tabular}{llll}
\hline Path Coefficient & $\mathbf{t}$ & $\mathbf{t}_{\text {-critical }}$ & Conclusion \\
\hline 0.364 & 2.558 & 1.96 & Significant \\
\hline
\end{tabular}

The t-test value of the path coefficients on business environment variable to the application of

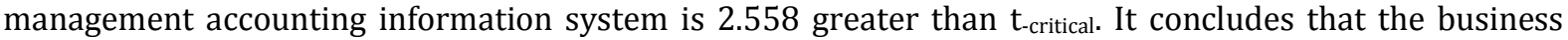
environment significantly influence the implementation of management accounting information systems. Based on the values contained in the structural model of the path diagram between the latent variables, it can be seen the influence the business environment on the application of management accounting information systems. The business environment directly influence the application of management accounting information system for $(0.364 \times 0.364 \times 100 \%)=13.2 \%$. So regardless of the relationship with other variables, the business environment provides influence of $13.2 \%$ on the application of management accounting information systems. While the business environment influences indirectly to the application of management accounting information systems because of the relationship with the ethics by $(0.364 \times$ $0.829 \times 0.484 \times 100 \%)=14.6 \%$ and business environment influences indirectly to the application of management accounting information systems due to relationship with organizational culture by $(0.364 \times$ $0.786 \times 0.166 \times 100 \%)=4.8 \%$. The magnitude of the effect of the business environment for the application of management accounting information systems is $32.6 \%$.

The magnitude of the determinant coefficient or contribution of business environment to the application of management accounting information system is $32.6 \%$. The business environment either directly or indirectly as through other exogenous variables (ethics and organizational culture) contributed partially to the application of management accounting information system by $32.6 \%$. These results indicate that the business environment is one of the factors that may play a role in determining the application of 
management accounting information systems. This is in accordance with the findings mentioned by Ajibolade (2010) states that environmental factors influence the application and design of management accounting information system. The quality of the application of management accounting emphasis on the organization's ability to adapt to changes in the corporate environment both internally and externally.

The Effect of Ethics on the Application of Management Accounting Information System: The ethics hypothesized to affect the application of management accounting information systems. Below are the results of significance test of the hypothesis:

Ho. $\gamma 2=0: \quad$ Ethics does not affect the application of management accounting information system.

Ha. $\gamma 2 \neq 0$ : $\quad$ Ethics affects the application of management accounting information system.

Table 4: Significance test of the Effect of Ethics on the Application of Management Accounting Information Systems

\begin{tabular}{llll}
\hline Path Coefficient & $\mathbf{t}$ & $\mathbf{t}_{\text {-critical }}$ & Conclusion \\
\hline 0.484 & 3.505 & 1.96 & Significant \\
\hline
\end{tabular}

The t-test value of the path coefficients on ethics variable to the application of management accounting information system is 3.505 greater than $t_{\text {-critical. }}$. It concludes that the ethics significantly influence the implementation of management accounting information systems. Based on the values contained in the structural model of the path diagram between the latent variables, it can be seen the influence the ethics on the application of management accounting information systems. The ethics directly influence the application of management accounting information system for $(0.484 \times 0.484 \times 100 \%)=23.4 \%$. So regardless of the relationship with other variables, the ethics provides influence of $23.4 \%$ on the application of management accounting information systems. While the ethics influences indirectly to the application of management accounting information systems because of the relationship with the business environment by $(0.484 \times 0.829 \times 0.364 \times 100 \%)=14.6 \%$ and ethics influences indirectly to the application of management accounting information systems due to relationship with organizational culture by $(0.484 \times 0.786 \times 0.364 \times 100 \%)=5.7 \%$. The magnitude of the effect of the ethics for the application of management accounting information systems is $43.7 \%$.

The results showed that the ethics affect the application of management accounting information systems by $43.7 \%$ which indicate that ethics is one of the factors that may play a role in determining the application of management accounting information systems. The ethics used by individuals to regulate their behavior, however, ethical errors can have major implications for the employees and organization. It is thus important to maintain ethics as moral framework when providing information to management as the output of management accounting information system. So that ethics is a strength for the application of management accounting information systems. Meanwhile the magnitude on the contribution (coefficient of determination/ $\mathrm{R}^{2}$ ) of exogeneous variables (business environment, ethics and organizational culture) simultenously on the endogeneous variable of application of management accounting information system by $89.5 \%$. The rest of $10.5 \%$ is influenced by other variables not examined in this study.

These results indicating that ethics used as one of the factors which may play a role in determining the application of management accounting information system is consistent with the findings mentioned by Kallapur and Krishnan in Chapmant et al. (2009, p. 1400) that ethics is an influential in accounting. This is supported by Brooks and Dunn (2010, p. 350) that it is important to adhere the ethical values which have been determined for professional accountants who work in management, as an employee or a consultant. Similarly revelead by Duska et al. (2011, p.230) that the practitioners of management accounting and financial management have an obligation to the community, their profession and organizations to maintain the highest standards of ethical codes. A study by conducted Vidya and Staehelin (1995) showed that there are some general approaches that can be used on cases of ethics in management accounting, while Bampton and Cowton (2002) revealed that it is important to do and discover aspects of ethics in management accounting. The importance of ethics in managerial accounting is geared towards business potential success or failure of a business. 
The Effect of Organizational Culture on the Application of Management Accounting Information System: The organizational culture hypothesized to affect the application of management accounting information systems. Below are the results of significance test of the hypothesis:

Ho. $3=0: \quad$ Organizational culture does not affect the application of management accounting information system.

Ha. $3 \neq 0$ : Organizational culture affects the application of management accounting information system.

Table 5: Significance test of the Effect of Organizational Culture on the Application of Management Accounting Information Systems

\begin{tabular}{llll}
\hline Path Coefficient & $\mathbf{t}$ & $\mathbf{t}_{\text {-critical }}$ & Conclusion \\
\hline 0.166 & 2.257 & 1.96 & Significant \\
\hline
\end{tabular}

The t-test value of the path coefficients on organizational culture variable to the application of management accounting information system is 2.257 greater than $t_{\text {-critical. }}$ It concludes that the organizational culture significantly influence the implementation of management accounting information systems. Based on the values contained in the structural model of the path diagram between the latent variables, it can be seen the influence the organizational culture on the application of management accounting information systems. The organizational culture directly influence the application of management accounting information system for $(0.166 \times 0.166 \times 100 \%)=2.8 \%$. So regardless of the relationship with other variables, the organizational culture provides influence of $2.8 \%$ on the application of management accounting information systems. While the organizational culture influences indirectly to the application of management accounting information systems because of the relationship with the business environment by $(0.166 \times 0.786 \times 0.364 \times 100 \%)=4.8 \%$ and organizational culture influences indirectly to the application of management accounting information systems due to relationship with ethics by $(0.166 \times 0.786 \times 0.484 \times 100 \%)=5.7 \%$. The magnitude of the effect of the organizational culture for the application of management accounting information systems is $13.2 \%$.

The results showed that the organizational culture affects the application of management accounting information systems by $13.2 \%$ which indicate that the organizational culture strengthen the application of management accounting information systems in the hotel services companies in North Sumatra. The organizational culture involves expectations, values, and attitudes that gives an effect to the individual, group, and organizational processes, so the organization is able to operate efficiently. The stronger the organizational culture in an organization, it will support the application of management accounting information systems. The organizational culture in hotel services companies supporting the application of management accounting information system, in which it been used as a tool to provide coordination, control and achieving efficiency in the business process.

The nation's corporate culture differences can result in different management accounting practices across the country. This asserted by Wagdy (2001, p.5-6) that the culture influences the selection of accounting systems and practices, while Schroeder et al. (2011) added that the culture of the country not only affects business practices but also the accounting system. Furthermore, Sisaye (2001, p.72) stated that the organizational culture established an accounting system to which extent the innovative plan in administrations' changes can be implemented.

The Effect of Application of Management Accounting Information Systems on Quality of Management Accounting Information: The management accounting information systems hypothesized to affect the quality of management accounting information. Below are the results of significance test of the hypothesis:

Ho. $\beta=0: \quad$ Application of management accounting information systems does not affect the quality of management accounting information.

Ha. $\beta \neq 0$ : Application of management accounting information systems affects the quality of management accounting information. 
Table 6: Significance test of the Effect of Application of Management Accounting Information Systems on Quality of Management Accounting Information

\begin{tabular}{llll}
\hline Path Coefficient & $\mathbf{t}$ & $\mathbf{t}_{\text {-critical }}$ & Conclusion \\
\hline 0.865 & 14.909 & 1.96 & Significant \\
\hline
\end{tabular}

The t-test value of the path coefficients on application of management accounting information systems variable to the quality of management accounting information is 14.909 greater than $t_{\text {-critical }}$. It concludes that the application of management accounting information systems significantly influence the quality of management accounting information. The magnitude of the effect of the application of management accounting information system on the quality of management accounting information is $(0.865 \times 0.865 \times$ $100 \%)=74.8 \%$. The results showed that the application of management accounting information system affects the quality of management accounting information by $74.8 \%$ which indicate that the quality of information refers to the quality of the output produced by the information system, thus the better the application of management accounting information systems can lead to the optimal achievement of quality management accounting information.

These results are in accordance with the findings mentioned by Duggan and Reichgelt $(2006, p .18)$ that the information system should collect the data and turn it into quality information. Furthermore Sacer et al. (2006, p.59) states that the quality of accounting information is a prerequisite to achieve the business objectives of the company, and obviously there is no quality of accounting information in the absence of accounting information systems. Turner and Weickgenannt (2009, p.245) added that the process-based information systems provide high-quality information to the management. Likewise revealed by Jackson et al. $(2009$, p.30) that the information system has several benefits to improve the speed and quality of the exchange of information, reduce lead time and processing costs. Based on these arguments, it can be concluded that the application of management accounting information system affects the quality of management accounting information.

Recommendation: Based on the phenomenon, the formulation of the problem, hypotheses and research results, the authors draw the following conclusions:

- The business environment affects the application of management accounting information systems.

- The ethics affects the application of management accounting information systems.

- The organizational culture affects the application of management accounting information systems.

- The application of management accounting information system affects the quality of management accounting information.

It is important for the organization to concern on the business environment, ethics and culture in applying the management accounting information systems especially among the companies in North Sumatera province. It may be happened in other regions/countries, however, the study can't be generalized due to having different culture and business environments for each of the regions. Moreover, it it demanded that the stakeholders will get the quality and credible information in accordance the organization operations.

\section{Reference}

Abernethy, M. A. \& Guthrie, C. H. (1994). An Empirical Assessment of the Fit between Strategy and Management Information System Design. Accounting and finance.

Ajibolade L. (2010). Management Accounting System, Perceived Environmental Uncertainty and Companies Performance in Nigeria. International Journal of Academic Research, 2(2).

Atkinson, A. A., Kaplan, E. \& Mae, M. (2012). Management Accounting: Information for Decision Making and Strategy Execution. 6th Edition. Prentice Hall

Azhar, S. (2008). Sistem Informasi Akuntansi: Struktur, Pengendalian, Resiko, Pengembangan,Jakarta: Lingga Jaya.

Bampton, R. \& Cowton, C. J. (2002). Pioneering in Ethics Teaching: The Case of Management Accounting in UK. Teaching Business Ethics.

Boyd, B. K. \& Fulk. J. (1996). Executive Scanning and Perceived Uncertainty: A Multidimensional Model. Journal of Management, 22, 1-21. 
Boyd, B. K., Dess, K. \& Rasheed, A. M. A. (1993). Divergence Between Archival and Perseptual Measures of Environment: Causes and Consequences. Academy of Management Review, 18, 204-226.

Brooks, L. J., \& Dunn, P. (2010). Business and Professional Ethics for Directors, Executives and Accountants. Fifth Edition. South Western Cengage Learning.

Cabrera, A. (2001). The Key Role of Organizational Culture in a Multi-System View of Technology-Driven Change. International Journal of Information, 21(3), 245-261.

Champoux, J. E. (2003). Organizational Behavior. Essential Tenets. Second Edition. Thomson South Western.

Chapman, C. S., Hopwood, A. G. \& Shields, M. P. (2009). Handbook of Management Accounting Research, 3.

Chenhall, R. H. \& Deigan, M. (1986). The Impact of Structure, Enviroment, and Interdependence on the Perceived Usefulness of Managerial Accounting Systems. The Accounting Review, LXI (1), 16-35.

Claver, E., Llopis, J. \& Gonzalez, M. R. (2001). The Performance of Information Systems through Organizational Culture.

DeLone, W., Petter, S. \& McLean, E. (2008). Measuring Information Systems Success: Models, Dimensions, Measures, and Interrelationships.

Duggan, E. W. \& Reichgelt, H. (2006). Measuring Information System Delivery Quality. Ide Group Inc.

Duncan, R. B. (1972). Characteristics of Organizational Environments and Perceived Environmental Uncertainty. Administrative Science Querterly, 2, 313-327.

Duska, R., Duska, B. S. \& Ragatz, J. A. (2011). Accounting ethics. Second edition. Wiley Blackwell.

Garrison, R., Noreen, E. \& Brewer, P. (2011). Managerial Accounting. 14th edition. McGraw Hill.

Ginandjar, K. (2010). Budaya Lokal Pengaruhi Kebijakan. Accessed at http://nasional.kompas.com/read/2010/07/13/18333613/Budaya.Lokal.Pengaruhi .Kebijakan.

Hansen \& Mowen. (2007). Managerial Accounting. 8th edition. Thomson South

Ivancevich, J. M., Konopaske, R. \& Matteson, M.T. (2011). Organizational behavior and Management. Ninth edition. McGraw Hill.

Leidner, D. E. \& Kayworth, T. (2006). A Review of Culture in Information Systems Research: Toward a Theory of Information Technology Culture Conflict. Management Information Systems Quarterly, $30(2)$.

Jackson, S. R., Sawyer, R. B., \& Jenkins, J G. (2009). Managerial Accounting Focus On Ethical Decision making. Fifth Edition. South Western Cengage Learning.

Khan, M. Y. \& Jain, P. K. (2007). Management Accounting:Text, Problem and Cases. Fourth edition. The McGraw Hill Companies.

Khomsiyah, \& Nur, I. (1998). Pengaruh Orientasi Etika terhadap Komitmen, dan Sensitivitas Etika Auditor pemerintah di DKI Jakarta. Jurnal Riset Akuntansi Indonesia, 1(1).

Loudon, K. C. \& Loudon, J. P. (2008). Essential of Management Information System: Managing the Digital System. Sixth Edition. Pearson Prentice Hall.

Lubis, A. I. (2010). Akuntansi Keperilakuan. Edisi 2. Penerbit Salemba Empat

Luthon, F. (2005). Organizational Behavior. Tents Edition. McGraw Hill International Edition

McLeod, R. \& Schell, G. P. (2007). Management Information System. Tenth Edition. Pearson Education,Inc

Mia, I. \& Robert, H. C. (1994). The usefulness of Management Accounting System Functional Differentiation and Managerial Effectiveness. Accounting, Organization and Society, 2, 1-13.

Milliken, F. J. (2001). Three Types of Perceived Uncertainty about Environment: State, Effect and Response Uncertainty. Academy of Management review, 12(1).

Mock, T. J. (1971). Concepts of Information Value and Accounting. The Accounting Review, 4, 765-778.

Robbins, S. P. \& Judge, T. A. (2007). Organizational Behavior. Twelfth Edition. Pearson Education Inc.

Sacer, I. M., Zager, K. \& Tusek, B. (2006). Accounting Information Systems Quality as The Ground For Quality Business Reporting. IADIS International Conference e-Commerce.

Schroeder, R. D., Clark, M. W. \& Cathey, J. M. (2011). Financial Accounting Theory and Analysis: Text And Cases. Tenth Edition. John Wiley \& Son.

Sekaran, U. \& Bougie, R. (2010). Reseach Method for Business: A skill Building Approach. John Wiley \& Sons Ltd. UK.

Sisaye, S. (2001). Organization Change and Development in Management Control System: Process Innovation for Internal Auditing And ManagementAaccounting. Elsevie Science ltd.

Turner, L. \& Weickgenannt, A. (2009). Accounting Information System: Controls and Process. John Wiley \& Sons Inc.

Otley, D. T. (1980). The Contingency Theory of Management Accounting: Achievement and Prognosis. Accounting, Organizations and Society, 3, 413-428.

Vanevenhoven, J. P. (2008). Taxonomies of Environmental Uncertainty Sources Perceived by Executives in The US, Taiwan and Mexico. Uni Microform. Copyright by Proquest LLC 
Vidya A. N. \& Staehelin, E. (1995). Ethics and Management Accounting. Journal of Accounting Education, 2(1).

Wagdy, M. A. (2001). Managing Multinationals in the Middle East: Accounting and Tax Issues. Greenwood Publishing Group. 